\title{
The Effect of Cerium on Microstructures and Mechanical Properties of Mg-4Al-2Sn-1Ca Alloy
}

\author{
Byeong Ho Kim ${ }^{1}$, Hisamichi Kimura ${ }^{2}$, Yong Ho Park ${ }^{1}$ and Ik Min Park ${ }^{1}$ \\ ${ }^{1}$ Department of Material Science and Engineering, Pusan National University, Busan 609-735, Korea \\ ${ }^{2}$ Institute for Materials Research, Tohoku University, Sendai 980-8577, Japan
}

\begin{abstract}
The development of new creep resistant magnesium alloys has become a major research focus. This study examined the microstructure and creep properties of Mg-4.0 mass \% Al-2.0 mass\% Sn-1.0 mass \% Ca alloys containing Ce. The results showed that Ce could improve dramatically the tensile strength and ductility of the alloy at room temperature and increase the creep resistance at elevated temperatures significantly. With a trace amount of $\mathrm{Ce}$, the morphology changed from a coarse $\mathrm{CaMgSn}$ phase to a refined shape and the microstructure of the alloy was remarkably refined. [doi:10.2320/matertrans.M2010042]
\end{abstract}

(Received February 4, 2010; Accepted April 5, 2010; Published May 26, 2010)

Keywords: magnesium alloys, microstructure, creep, CaMgSn

\section{Introduction}

As one of the lightest structural metal materials available, magnesium alloys are the most attractive candidates for automotive and aerospace applications. ${ }^{1,2)}$ However, these alloys need to meet certain mechanical criteria when used for structural applications. Mg-Al based alloys, such as AZ91D and AM60B, which exhibit superior die castibility and a good balance of strength and ductility, have been used increasingly in automotive products. However, these alloys have poor creep resistance at temperatures above $125^{\circ} \mathrm{C}$, making them unsuitable for major engine and power-train components. ${ }^{3-5)}$ Early developed creep-resistant $\mathrm{Mg}$-Al based alloys were based on the Mg-Al-RE (AE series) and Mg-Al-Si (AS series) systems. The disadvantages of both alloy systems, such as the high cost or less than optimal properties, has prompted further research. ${ }^{6-8)}$ The addition of Sn and alkaline earth metals ( $\mathrm{Sr}$ and $\mathrm{Ca}$ ) is a potential way of producing heatresistant $\mathrm{Mg}-\mathrm{Al}$ alloys due to the formation of highly stable intermetallic compounds. Several studies ${ }^{9-11)}$ reported that $\mathrm{Mg}-\mathrm{Sn}-\mathrm{Ca}$ and $\mathrm{Mg}-\mathrm{Al}-\mathrm{Sn}-\mathrm{Ca}$ based alloys exhibit good creep resistance at low cost. However, there are only a few reports on the Mg-Al-Sn-Ca quaternary system. The results reported in previous work showed that the addition of $\mathrm{Sn}$ and $\mathrm{Ca}$ to the binary alloy, $\mathrm{Mg}-4 \mathrm{Al}$, is quite effective in improving the creep resistance at temperatures $>150^{\circ} \mathrm{C} .^{12,13)}$ This paper reports the effects of the trace element $\mathrm{Ce}$ on the microstructure, tensile and creep properties of $\mathrm{Mg}-4 \mathrm{Al}-2 \mathrm{Sn}-1 \mathrm{Ca}$ alloys to provide a reference for the development of creep resistant magnesium alloys.

\section{Experimental Procedures}

Mg-4.0 mass\%Al-2.0 mass\% $\mathrm{Sn}-1.0$ mass\%Ca and 1.0 mass\%Ce (simply noted as $\mathrm{Mg}-4 \mathrm{Al}-2 \mathrm{Sn}-1 \mathrm{Ca}$ and $\mathrm{Mg}-4 \mathrm{Al}-$ $2 \mathrm{Sn}-1 \mathrm{Ca}-1 \mathrm{Ce}$ in this paper) containing alloys were prepared from high purity magnesium (99.9\%), aluminum (99.99\%), tin (99.9), and $\mathrm{Mg}-40$ mass\% $\% \mathrm{Ca}$ and $\mathrm{Mg}-40$ mass\%Ce master alloys. The alloys were melted at $750^{\circ} \mathrm{C}$ in a mild steel crucible under a $\mathrm{CO}_{2}+\mathrm{SF}_{6}$ atmosphere and then poured into preheated permanent mold at $200^{\circ} \mathrm{C}$. The samples selected at the corresponding position were homogenized at $420^{\circ} \mathrm{C}$ for $4 \mathrm{~h}$ in order to delineate the grains. Microstructural analysis was carried out using an optical microscope and a scanning electron microscope equipped with an energy dispersive $\mathrm{X}$-ray spectrometer. The phases of the as-cast alloys were examined by X-ray diffraction (XRD) using monochromatic $\mathrm{CuK} \alpha$ radiation. The tensile and creep test specimens were $3 \mathrm{~mm} \times 6 \mathrm{~mm} \times 30 \mathrm{~mm}$ in size. The tensile tests were performed at an initial engineering strain rate of $3.33 \times$ $10^{-2} \mathrm{~s}^{-1}$ at room temperature. The tensile creep tests were conducted using a lever arm type creep tester in a box chamber $(450 \mathrm{~mm} \times 250 \mathrm{~mm} \times 250 \mathrm{~mm})$ for temperature control. The creep tests were carried out at constant temperatures between $150^{\circ} \mathrm{C}$ and $200^{\circ} \mathrm{C}$ and at constant applied stresses of $70 \mathrm{MPa}$. The tests were performed until the specimen broke or the minimum creep rate averaged over three tests had been reached.

\section{Results and Discussion}

\subsection{Microstructure}

Figure 1 shows the XRD patterns of the as-cast Mg-4Al$2 \mathrm{Sn}-1 \mathrm{Ca}$ alloys. The XRD results showed that the Mg-4Al$2 \mathrm{Sn}-1 \mathrm{Ca}$ alloy was composed mainly of $\alpha-\mathrm{Mg}$ (hexagonal, $\mathrm{P6}_{3} / \mathrm{mmc}$ ), $\mathrm{Mg}_{17} \mathrm{Al}_{12}$ (Cubic, İ̈3m), $\mathrm{Mg}_{2} \mathrm{Sn}$ (Cubic, Fm3m) and $\mathrm{CaMgSn}$ (Orthorhombic, Pnma) phase. With the addition of $\mathrm{Ce}$, peaks for an $\mathrm{Al}_{11} \mathrm{Ce}_{3}$ phase appeared. Figure 2 shows the microstructures of the as-cast and homogenized $\mathrm{Mg}-4 \mathrm{Al}-$ 2Sn-1Ca and the Mg-4Al-2Sn-1Ca-1Ce alloys. The CaMgSn phase was distributed in the grain interior of the $\mathrm{Mg}-4 \mathrm{Al}-$ 2Sn-1Ca alloy, and the $\mathrm{Mg}_{17} \mathrm{Al}_{12}$ and $\mathrm{Mg}_{2} \mathrm{Sn}$ phase formed at the grain boundaries (Fig. 2(a)). With the addition of 1.0 mass $\% \mathrm{Ce}$, the microstructure of the as-cast $\mathrm{Mg}-4 \mathrm{Al}-2 \mathrm{Sn}-$ $1 \mathrm{Ca}$ alloy was remarkably refined and the morphology changed from a coarse $\mathrm{CaMgSn}$ phase to a refined shape (Fig. 2(b)). The distribution coefficient of the solute Ce was found to be $<1$ according to the fundamentals of solidification and the binary phase diagram of the $\mathrm{Mg}$-Ce system. Therefore, solute Ce atoms are enriched in the liquid ahead of the solid-liquid interface during the solidification process. ${ }^{14)}$ This might result in constitutional undercooling and a 


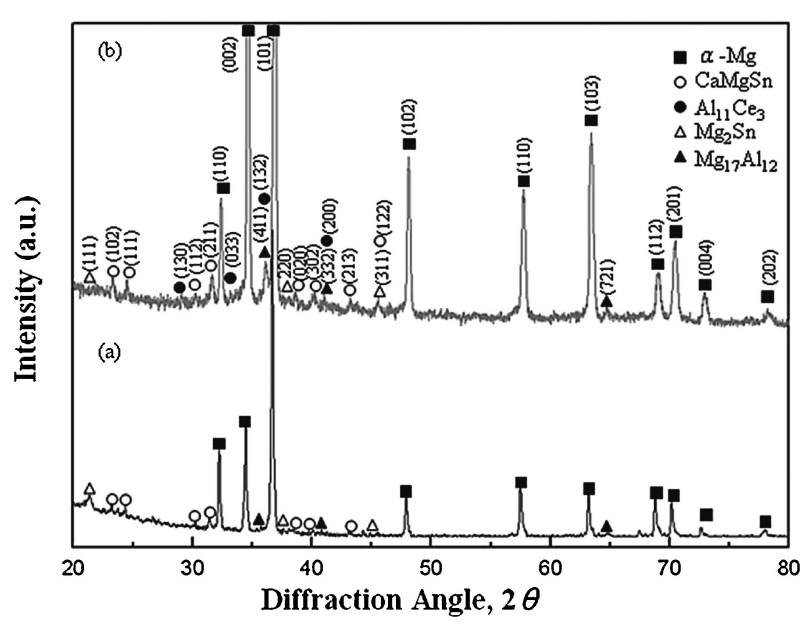

Fig. 1 XRD patterns of as-cast alloys: (a) Mg-4Al-2Sn-1Ca, (b) Mg-4Al$2 \mathrm{Sn}-1 \mathrm{Ca}-1 \mathrm{Ce}$.

decrease in rate of Sn and Ca diffusion, which would increase the number of nuclei and restrict the growth of the CaMgSn phase. However, the reason for the morphology change in the $\mathrm{CaMgSn}$ phase in the Ce-containing $\mathrm{Mg}-4 \mathrm{Al}-2 \mathrm{Sn}-1 \mathrm{Ca}$ alloy is unclear and further study will be needed. Figure 2(c)-(d) shows the microstructures of the homogenized alloys. With the addition of 1.0 mass $\% \mathrm{Ce}$, the mean grain sizes of the Mg-4Al-2Sn-1Ca alloy decreased from 105 to $63 \mu \mathrm{m}$. The reduced grain size by $\mathrm{Ce}$ addition might be due to the enrichment of solute atoms leading to the formation of $\mathrm{Al}_{11} \mathrm{Ce}_{3}$ phase, which are distributed mainly in the grain boundary areas, further restricting grain growth. ${ }^{12)}$
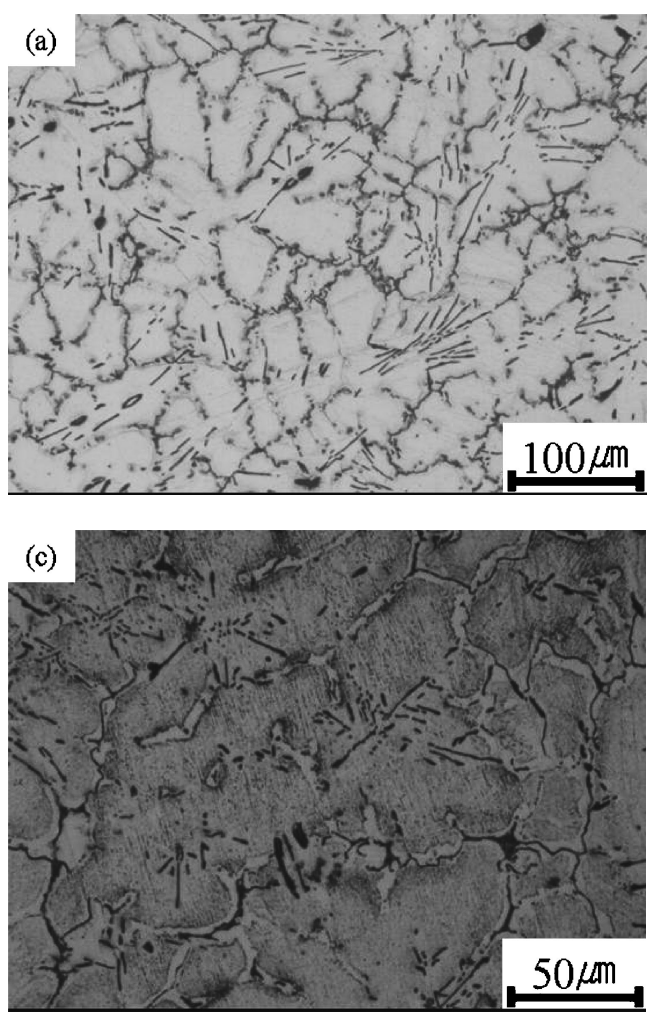

\subsection{Tensile properties}

Figure 3 shows the stress-strain curves and fractography of the alloys tested at room temperature. As shown in Fig. 3(a), the ultimate tensile strength and elongation of the as-cast $\mathrm{Mg}$ 4Al-2Sn-1Ca alloy were $150 \mathrm{MPa}$ and $5.5 \%$ respectively, while the ultimate tensile strength and elongation of the $\mathrm{Mg}$ $4 \mathrm{Al}-2 \mathrm{Sn}-1 \mathrm{Ca}-1 \mathrm{Ce}$ alloy were $194 \mathrm{MPa}$ and $11.4 \%$ respectively. The addition of 1 mass $\%$ Ce to the alloy had an effect on the mechanical properties of the $\mathrm{Mg}-4 \mathrm{Al}-2 \mathrm{Sn}-1 \mathrm{Ca}$ alloy. Both the fracture strength and ductility increased. This situation was possibly related to the refinement of the $\mathrm{CaMgSn}$ phase in the $\mathrm{Mg}-4 \mathrm{Al}-2 \mathrm{Sn}-1 \mathrm{Ca}-1 \mathrm{Ce}$ alloy. It is well known that the initiation of microcracks can be greatly influenced by the presence and nature of the second phase. ${ }^{7)}$ A common situation is for the particle to be cracked during deformation. Resistance to cracking is improved if the particle is well bonded to the matrix. Small and spherical particles are more resistant to cracking. However, the bigger the particle size is, the more easily the particle can be fractured. Addition of 1 mass $\% \mathrm{Ce}$ content resulted in the morphological change from coarse $\mathrm{CaMgSn}$ to a refined shape. In addition, grain size was decreased from 105 to $63 \mu \mathrm{m}$. Therefore, the tensile strength of as-cast $\mathrm{Mg}-4 \mathrm{Al}-$ $2 \mathrm{Sn}-1 \mathrm{Ca}-1 \mathrm{Ce}$ alloy was enhanced by second phase strengthening and fine grain strengthening.

As shown in Fig. 3(b)-(c), the fracture surface of the $\mathrm{Mg}$ 4Al-2Sn-1Ca alloy exhibited large cleavage-type facets (arrow ' $\mathrm{A}$ ' in Fig. 3(b)). Apparently, the coarse CaMgSn phase in the $\mathrm{Mg}-4 \mathrm{Al}-2 \mathrm{Sn}-1 \mathrm{Ca}$ alloy would have a detrimental effect on the room temperature mechanical properties because the cracks could easily nucleate along the interface
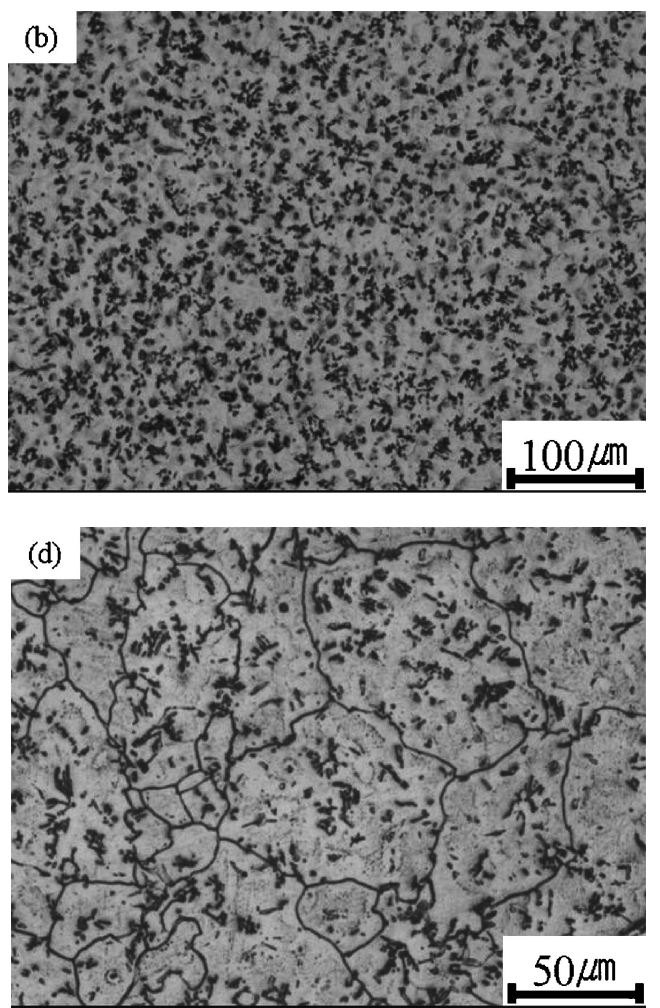

Fig. 2 Optical micrographs of as-cast (a) Mg-4Al-2Sn-1Ca and (b) Mg-4Al-2Sn-1Ca-1Ce alloys and homogenized (c) Mg-4Al-2Sn-1Ca and (d) Mg-4Al-2Sn-1Ca-1Ce alloys. 

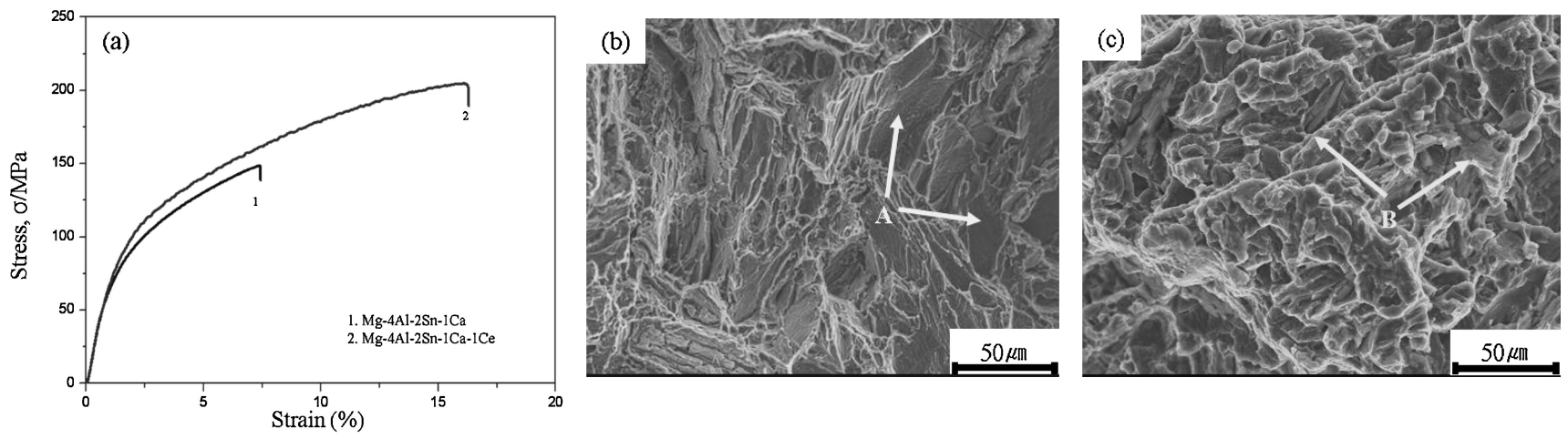

Fig. 3 Stress-strain curves (a) and fractography of the as-cast alloys (b) $\mathrm{Mg}-4 \mathrm{Al}-2 \mathrm{Sn}-1 \mathrm{Ca}$ and (c) $\mathrm{Mg}-4 \mathrm{Al}-2 \mathrm{Sn}-1 \mathrm{Ca}-1 \mathrm{Ce}$ at room temperature.
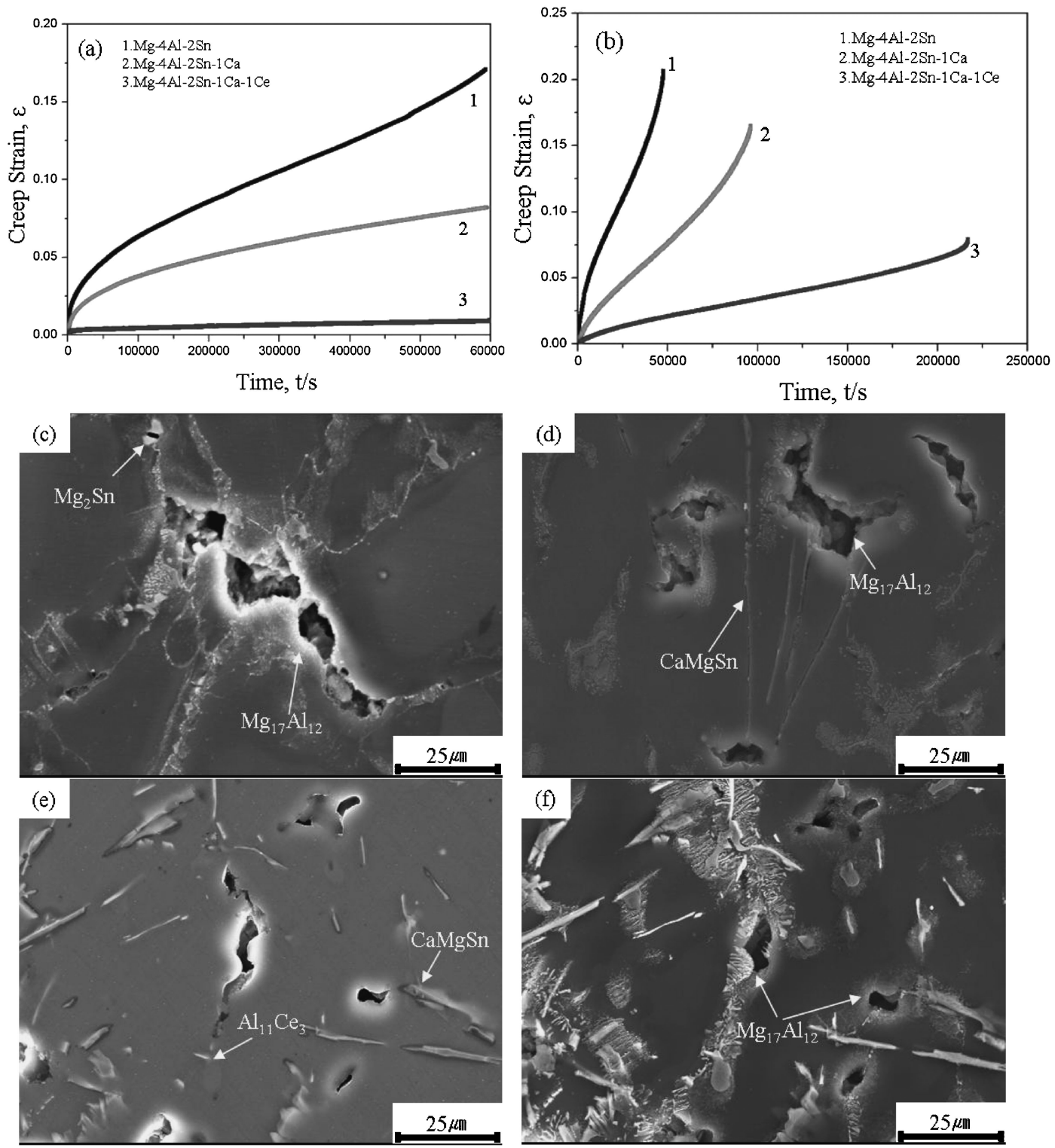

Fig. 4 Creep curves at (a) $150^{\circ} \mathrm{C}, 70 \mathrm{MPa}$ and (b) $200^{\circ} \mathrm{C}, 70 \mathrm{MPa}$ and SEM micrographs of transverse section of the (c) etched Mg- $4 \mathrm{Al}-$ 2Sn and (d) Mg-4Al-2Sn-1Ca alloy and (e) non-etched and (f) etched Mg-4Al-2Sn-1Ca-1Ce alloy after creep at $200^{\circ} \mathrm{C}, 70 \mathrm{MPa}$.

between the CaMgSn phase and $\alpha-\mathrm{Mg}$ matrix. Figure 3(a) highlights the difference in the tensile properties of the ascast alloys. On the other hand, the fracture surfaces of the $\mathrm{Mg}-4 \mathrm{Al}-2 \mathrm{Sn}-1 \mathrm{Ca}-1 \mathrm{Ce}$ alloy showed only small cleavage- type facets (arrow 'B' in Fig. 3(c)). This might be one reason for the difference in the tensile properties, particularly the elongation of the Mg-4Al-2Sn-1Ca alloys with and without $\mathrm{Ce}$ addition. 


\subsection{Creep behavior}

Figure 4 shows the creep curves of the as-cast alloys obtained at $150^{\circ} \mathrm{C}, 200^{\circ} \mathrm{C}$ and $70 \mathrm{MPa}$ and SEM micrographs of transverse section of the $\mathrm{Mg}-4 \mathrm{Al}-2 \mathrm{Sn}$ alloys after creep. The as-cast $\mathrm{Mg}-4 \mathrm{Al}-2 \mathrm{Sn}-1 \mathrm{Ca}$ and $\mathrm{Mg}-4 \mathrm{Al}-2 \mathrm{Sn}-1 \mathrm{Ca}-1 \mathrm{Ce}$ alloys exhibited higher creep-resistance than the $\mathrm{Mg}-4 \mathrm{Al}-$ 2Sn alloy. The high creep-resistant properties of $\mathrm{Mg}-4 \mathrm{Al}-$ 2Sn-1Ca and $\mathrm{Mg}-4 \mathrm{Al}-2 \mathrm{Sn}-1 \mathrm{Ca}-1 \mathrm{Ce}$ alloys were attributed mainly to the $\mathrm{CaMgSn}$ and $\mathrm{Al}_{11} \mathrm{Ce}_{3}$ phase in the alloys.

In general, the increase in the volume fraction of the thermally stable phases for magnesium alloys commonly results in an increase in creep-resistance. ${ }^{13)}$ Therefore, the minimum creep rate of the $\mathrm{Mg}-4 \mathrm{Al}-2 \mathrm{Sn}$ alloys at $150^{\circ} \mathrm{C}$ and $70 \mathrm{MPa}$ changes from $1.01 \times 10^{-7}$ to $9.15 \times 10^{-9} \mathrm{~s}^{-1}$, indicating that the presence of $\mathrm{Ce}$ in the $\mathrm{Mg}-4 \mathrm{Al}-2 \mathrm{Sn}-1 \mathrm{Ca}-$ $1 \mathrm{Ce}$ alloy improves the creep-resistance. Figure 4(c)-(f) shows SEM images of Mg-4Al-2Sn alloys obtained after creep rupture at $200^{\circ} \mathrm{C}$ and $70 \mathrm{MPa}$. Voids were initiated mainly at the $\mathrm{Mg}_{17} \mathrm{Al}_{12}$ phase and cracks propagated along the grain boundaries, suggesting that deformation by boundary sliding played an important role during the creep of these alloys. However, the propagation of cracks normally stopped in front of the $\mathrm{CaMgSn}$ or $\mathrm{Al}_{11} \mathrm{Ce}_{3}$ phase, indicating that the existence of these two phases inhibits sliding of the grain boundaries.

\section{Conclusions}

With the addition of 1.0 mass $\% \mathrm{Ce}$, the average grain size of primary $\alpha-\mathrm{Mg}$ phase in the as-cast $\mathrm{Mg}-4 \mathrm{Al}-2 \mathrm{Sn}-1 \mathrm{Ca}$ alloy decreased from 105 to $63 \mu \mathrm{m}$ and the refined CaMgSn phase was distributed uniformly within the grains of the as-cast $\mathrm{Mg}-4 \mathrm{Al}-2 \mathrm{Sn}-1 \mathrm{Ca}$ alloys. The ultimate tensile strength and elongation of the as-cast $\mathrm{Mg}-4 \mathrm{Al}-2 \mathrm{Sn}-1 \mathrm{Ca}-1 \mathrm{Ce}$ alloy were $194 \mathrm{MPa}$ and $11.4 \%$, respectively. The creep resistance was increased significantly by the addition of $\mathrm{Ce}$ due to the formation of thermally stable $\mathrm{Al}_{11} \mathrm{Ce}_{3}$ phase in the grain boundaries. The addition of $\mathrm{Ce}$ in the $\mathrm{Mg}-4 \mathrm{Al}-2 \mathrm{Sn}-1 \mathrm{Ca}$ alloy led to the formation of a fine $\mathrm{CaMgSn}$ phase and a thermally stable second phase in the as-cast alloy, which accounted for the improvement in the tensile and creep properties in the Mg-4Al-2Sn-1Ca alloy.

\section{Acknowledgements}

This work was supported by the National Core Research Center Program (NO. R15-2006-022-02001-0) from the Korea Science \& Engineering Foundation and a grant-inaid for the Tohoku University Global COE program.

\section{REFERENCES}

1) G. B. Hamu, D. Eliezer and K. S. Shin: Mater. Sci. Eng. A 447 (2007) $35-43$.

2) S. Cohen, G. R. Goren-Muginstein, S. Avraham, G. Dehm and M. Bamberger: Magnesium Technology 2004, ed. by A. A. Luo, (2004) pp. 301-305.

3) M. S. Dargusch, S. M. Zhu, J. F. Nie and G. L. Dunlop: Scr. Mater. 60 (2009) 116-119.

4) M. O. Pekguleryuz and A. A. Kaya: Adv. Eng. Mater. 5 (2003) 866878.

5) A. A. Luo: Int. Mater. Rev. 49 (2004) 13-30.

6) S. Xue, Y. S. Sun, S. S. Ding, Q. Bai and J. Bai: Mater. Sci. Technol. 21 (2005) 847-853.

7) B. H. Kim, J. J. Jeon, K. C. Park, B. G. Park, Y. H. Park and I. M. Park: Int. J. Cast. Metals Res. 21 (2008) 186-192.

8) S. M. Zhu, M. A. Gibson, J. F. Nie, M. A. Easton and T. B. Abbott: Scr. Mater. 58 (2008) 477-480.

9) M. Yang, F. Pan, L. Cheng and J. Shen: Mater. Sci. Eng. A 512 (2009) $132-138$.

10) A. L. Bowles, H. Dieringa, C. Blawert, N. Hort and K. U. Kainer: Mater. Sci. Forum 488-489 (2005) 135-138.

11) N. Hort, Y. Huang, T. A. Leil, P. Maier and K. U. Kainer: Adv. Eng. Mater. A 8 (2006) 359-364.

12) J. Zhang, D. Zhang, Z. Tian, J. Wang, K. Liu, H. Lu, D. Tang and J. Meng: Mater. Sci. Eng. A 489 (2008) 113-119.

13) J. J. Jeon, B. G. Park, Y. H. Park, I. M. Park, J. J. Oak and H. Kimura: Mater. Trans. 50 (2009) 1404-1410.

14) N. Hort, Y. Huang and K. U. Kainer: Adv. Eng. Mater. A 8 (2006) $235-240$. 